\title{
OCHRONA PRAW OSOBY LUDZKIEJ W KANONICZNYM PRAWIE PROCESOWYM
}

1. Godność człowieka ujawnia się w dramacie. Tak przynajmniej twierdzą filozofowie, którzy widząc trudność w jej zdefiniowaniu, wolą odwołać się do doświadczenia. To właśnie w dramacie, a więc tam gdzie ma on swój początek, czyli na scenie greckiego teatru, gdzie po raz pierwszy pojawiło się pojęcie osoby, człowiek doświadczył swojej godności i w sposób szczególny doświadcza jej w dramatycznych czy tragicznych sytuacjach życia, doświadcza indywidualnie i zbiorowo jako społeczność. Zwłaszcza kiedy człowiek znajduje się w sytuacji zagrożenia, wówczas gdy nie może już ocalić życia, chce zachować i odsłania swoją godność, odczuwa ją i doświadcza tej godności ${ }^{1}$.

2. Z ludzką godnością związane jest nierozdzielnie pojęcie człowieka jako osoby. Fundamentem bowiem godności czlowieka nie jest to, że jest on inny od reszty świata, że jest po prostu inną formą bytu, ale jest nim możność każdej jednostki ludzkiej do samookreślenia się w oparciu o poznaną prawdę ${ }^{2}$. Jest nim, innymi słowy, wolność rozumiana jako zdolność podejmowania decyzji, dokonywania wyboru, zależna wyłącznie od własnego ,ja”. W odróżnieniu od otaczającej go przyrody człowiek nie powstaje w wyniku organizowania się materii, lecz zaistniawszy w materii, sam ją przetwarza dla celów pozamaterialnych ${ }^{3}$. Poprzez nieustanne doświadczanie samego siebie i działanie nacechowane wolnością, człowiek tworzy swój niepowtarzalny osobowy profil, swój świat, niemal swój kosmos, jest sam dla siebie bytem zupełnym, tworzącym najwyższą całość bytową. Człowiek w ten sposób spełnia się, pozostając zawsze otwartym na inne światy, które go otaczają, a więc na innego człowieka, ostatecznie zaś na transcendentne „Ty” Absolutu 4 .

3. Otwarcie się na innego człowieka, uznanie jego wartości wynika ze spełnienia się człowieczeństwa w osobie ludzkiej, która może dostrzec swoją wartość tylko dzięki odniesieniu jej do innego człowieka, równie jak on stanowią-

\footnotetext{
* W przypisach i tekście artykułu zastosowano następujące skróty:

AAS - „Acta Apostolicae Sedis”.

RH - Redemptor hominis (zob. niżej przypis 9).

${ }^{1}$ J. T i s ch n e r, Rodowód ludzkiej godności, ,W Drodze” 4(152): 1986, s. 49-51.

2 T. S t y czeń, Mitość a sens życia. Nad encyklikq Jana Pawta II „,Redemptor hominis”,[w:] $\mathrm{J}$ a n P a weł II, Redemptor hominis. Tekst $i$ komentarze, Lublin 1982, s. 90-95; Z. Z d y b ick a, Personalistyczne podstawy prawdy o cztowieku zbawionym, tamże, s. 117.

${ }^{3}$ M. K rą piec, Cztowiek i prawo naturalne, Lublin 1975, s. 152.

${ }^{4}$ Tamże, s. 153.
} 
cego wartość. Taka afirmacja drugiego ze względu na niego samego jest po prostu miłością i prowadzi do odkrycia prawdy o godności człowieka jako osoby. Jest to równoznaczne $\mathrm{z}$ uświadomieniem sobie „powinności afirmowania osoby bez względu na cokolwiek innego poza tą jej godnością, powinności afirmowania osoby dla niej samej"5.

W ten sposób dochodzimy do stwierdzenia, że osoba ludzka jest podmiotem prawa naturalnego. Rozwój człowieka, polegający na osiąganiu przez niego osobowego dobra, może się dokonywać tylko w relacji do innych osób i ich rozwoju. Drogą do tego rozwoju jest przetwarzanie świata przez człowieka, dzięki czemu potrafi on wyrazić wyższość ludzkiego ducha w stosunku do materii. Nie może się to odbyć inaczej jak tylko na tej zasadzie, że pewne ludzkie działania, lub powstrzymanie się od działań, są wzajemnie ludziom należne, a należność jest charakterystyczną cechą interpersonalnej relacji prawnej6.

4. Godność człowieka jako osoby przejawia się w tym, że jest on celem, a nie środkiem w ludzkim działaniu. Jeżeli jednak wyznacznikiem godności człowieka jest jego wolność w sferze dóbr czysto osobowych, to konsekwentnie, ograniczeniem jego wolności będzie inna osoba, równie jak on wolna ${ }^{7}$. Powstaje zatem zagadnienie stosunku czlowieka do społeczności ludzkiej, jakąkolwiek byłaby ta społeczność. W wizji człowieka-osoby społeczność spełnia rolę wtórną, służebną i jest powołana do stwarzania tej osobie możliwie najlepszych warunków rozwoju. O ile jednak człowiek w przejawach duchowych życia osobowego jest całkowicie niezależny i podlega jedynie własnemu sumieniu, o tyle we wszystkich innych sprawach, z racji tworzenia dobra wspólnego jest podporządkowany społeczności. Przejawia się to w sferze dóbr materialnych, w stosunku do których, w pewnych sytuacjach, ludzka wolność może być słusznie ograniczona przez społeczność ${ }^{8}$.

5. Jeżeli w świetle rozumowania czysto filozoficznego jesteśmy w stanie dostrzec wielką godność człowieka i wynikające z niej ludzkie prawa, to cóż dopiero gdy sięgniemy do prawdy o człowieku w świetle Objawienia. Człowiek stworzony na obraz i podobieństwo Boże, mimo różnorodnych słabości którym podlega, a nawet mimo grzechu, nie tylko może odczytać prawdę o sobie w Chrystusie, który „objawia w pełni człowieka samemu człowiekowi” i w którym odnajduje „swoją właściwą wielkość, godność i wartość swojego człowieczeństwa" (RH 10) ${ }^{9}$, ale otwierając się osobowym aktem miłości na rzeczywistość Wcielenia i Odkupienia może zrealizować pełnię swojego człowieczeństwa w Bogu. To właśnie Chrystus przez swoje życie, śmierć i zmartwychwsta-

${ }^{5}$ T. Styczeń, jw., s. 90-95.

${ }^{6}$ M. Krą piec, Cztowiek a prawo naturalne..., s. 151-152.

${ }^{7}$ M. Krąpiec, Osoba i spoteczność, [w:] J a n Pawel II, Redemptor hominis. Tekst $i$ komentarze, Lublin 1982, s. 69-70.

${ }^{8}$ M. Krapi e c, Cztowiek i prawo naturalne..., s. 190-191.

${ }^{9}$ Encyklika papieża Jana Pawła II Redemptor hominis (AAS 71 : 1979 s. 257-324). 
nie, przy dobrowolnej współpracy człowieka, przywraca mu zatarty przez grzech obraz Boży, wyzwala go do pełnego i prawdziwego człowieczeństwa ${ }^{10}$.

6. Wielkim zagrożeniem ludzkiej godności jest naruszanie obiektywnych i nienaruszalnych praw człowieka. Nie jest to problem nowy, pojawił się bowiem na świecie wraz z człowiekiem, przynajmniej z takim jakiego dzisiaj znamy, niemniej jest rzeczą zastanawiającą, dlaczego trzeba było czekać aż tyle wieków na sformułowanie katalogu nienaruszalnych praw człowieka, co, jak wiemy, zostało dokonane dopiero przez Organizację Narodów Zjednoczonych w 1948 r. Sądzę, że była to w dużej mierze sprawa dojrzewania ludzkiej świadomości i dramatów, przez jakie przyszło człowiekowi przejść. Wiek XX był rzeczywiście sceną wielkich tragedii, był wiekiem „w którym ludzie ludziom ogromnie wiele zgotowali krzywd i cierpień" (RH 17). Te straszliwe sytuacje w skali dotąd nie spotykanej, odsłaniające niejako samo dno zła, do którego człowiek może sięgnąć przeciw człowiekowi, w sposób szczególny ukazały też światu ludzką godność, ten ostateczny argument za człowiekiem. Wiemy, że uchwalenie „Powszechnej karty praw człowieka” nie jest równoznaczne z przestrzeganiem zawartych $w$ niej praw ${ }^{11}$, ale jest niewątpliwie znakiem, że ludzie zaczynają szukać sposobów ochrony własnych praw proporcjonalnie do skali nieszczęść, które ich spotkały i że ta obrona ich jednoczy.

7. Prawa człowieka były dla Kościoła katolickiego zawsze sprawą ważną i bliską, bo idea prawa naturalnego, z którego one wynikają (a w rozumieniu chrześcijańskim jest to prawo Boże), leżała u podstaw oceny wszelkich spraw ludzkich. Prawdą jest jednak, że do katalogów praw człowieka, które pojawiły się jako forma buntu przeciwko absolutyzmowi nowoczesnego państwa, Kościół ustosunkował się z dużą rezerwą, a nawet wyrażał wobec nich swoją wrogość. Historia kontaktów Kościoła z prawami człowieka, tak jak je dzisiaj rozumiemy, rozpoczyna się z pontyfikatem pap. Leona XIII, by nabierać na sile aż po czasy dzisiejsze, w których Kościół może być uważany za pierwszego rzecznika praw człowieka ${ }^{12}$.

By wyjaśnić co stało u podstaw nieufności Kościoła w stosunku do formułowanych na przestrzeni ostatnich wieków niezbywalnych praw człowieka, trzeba sięgnąć do myśli filozoficznej minionych wieków, która ukształ towała profil historyczny praw człowieka. Początków tej nieufności należy szukać w późnym średniowieczu, kiedy idee różnic narodowych i suwerenności państwa zostaly oparte na zasadzie oddzielenia polityki od moralności. To Macchiavelli umożliwił teoretyczne uzasadnienie indywidualizmu, który wyniósł państwo i jego

${ }^{10}$ W. Hryniewicz, W gtąb tajemnicy odkupienia. Doniostość soteriologicznej nauki Jana Pawta II, [w:] J a n P a weł II, Redemptor hominis. Tekst $i$ komentarze, Lublin 1982, s. 188-194.

11 Szeroka panorama nieprzestrzegania praw człowieka w świecie współczesnym została przedstawiona w dziele zbiorowym pod red. G. Concettiego: I diritti umani. Dottrina e prassi, Roma 1982, s. 825-868.

12 F. Biffi, I diritti umani da Leone XIII a Giovanni Paolo II, [w:] I diritti umani..., s. $199-243$. 
władzę do roli suwerena nie tylko w polityce, ale i w dziedzinie moralności. Władza państwowa została w ten sposób zaopatrzona w możliwość tłumaczenia racją stanu każdej sytuacji według własnej woli. Dalszy rozwój idei suwerenności państwa poszedł w kierunku przyznania mu wszelkich kompetencji, także w dziedzinie religii i sumienia, co wiązało się z protestancką myślą uznającą państwo za najdoskonalszy twór Boga. Zasada, że państwo nie podlega żadnym zobowiązaniom, których samo na siebie nie przyjęło, doprowadziła z czasem do odrzucenia przez wyznające tę ideologię rządy, wszelkich zobowiązań traktatowych, które nie były dla nich korzystne. Biorąc ponadto pod uwagę, że filozofia prawa była w tym czasie zdominowana przez pozytywizm prawny odrzucający wszelkie normy, których autorem nie było samo państwo, oraz przez pozytywizm moralny, traktujący moralność jako zjawisko psychologiczne lub socjologiczne, łatwo zrozumieć, dlaczego Kościół nie mógł sprzyjać chwytliwie sformułowanym hasłom praw człowieka, za którymi stała ideologia tak zasadniczo sprzeczna z chrześcijańską wizją godności człowieka ${ }^{13}$.

8. Urząd Nauczycielski Kościoła poszedł jednak również w kierunku sformułowania praw człowieka ${ }^{14}$, chociaż dokonał tego na nieco innej drodze. Nastąpiło to wprawdzie z pewnym opóźnieniem, ale za to zostało oparte na solidnym fundamencie poszanowania godności każdego z osobna człowieka, wypływającej z jego naturalnego i nadprzyrodzonego powołania.

Działalność Kościoła w tej dziedzinie, polegająca na zajmowaniu przezeń stanowiska wobec dokonujących się w świecie przemian społecznych i burzliwych dziejów politycznych drugiej połowy XIX w. i wieku XX aż po nasze czasy, doprowadziła kolejno do rozwinięcia katolickiej nauki społecznej i do zainteresowania się Kościoła wprost problematyką praw człowieka. Etapami na tej drodze przebytej przez Kościół były niewątpliwie wielkie encykliki społeczne zapoczątkowane przez Rerum novarum pap. Leona XIII, zaś największe znaczenie w określeniu stanowiska Kościoła wobec praw człowieka przypisać należy encyklikom pap. Jana XXIII Mater et Magistra i Pacem in terris. Od tego czasu Kościół stara się bardzo zdecydowanie o to, by uświadomić, zwłaszcza swoim wiernym, ale także i całemu światu znaczenie przestrzegania praw człowieka dla zachowania pokoju i obrony godności człowieka ${ }^{15}$.

Jeżeli zapytalibyśmy o przyczyny takiego zwrotu, to wydaje się, że nie są one łatwe do określenia. Nie ulega jednak wątpliwości, że bardzo ważnym mo-

${ }^{13} \mathrm{D}$. Co m post a, I diritti umani dal medioevo all' età moderna, [w:] I diritti umani..., s. 165198; D. Pa s in i, I diritti dell'uomo. Saggi di filosofia politico-giuridica, Napoli 1979, s. 9 nn.; Papież J a n XXIII, Encyklika o pokoju między wszystkimi narodami, opartymi na prawdzie, sprawiedliwości, mitości i wolności (Pacem in terris), [Société d'Édition Internationales], Paris 1964, s. 12-15.

${ }^{14} \mathrm{E}$. Co r e c co, Il catalogo dei doveri-diritti del fedele nel CJC, [w:] I diritti fondamentali della persona umana e la libertà religiosa. Atti del $V$ colloquio giuridico (8-10 marzo 1984) a cura di $\mathrm{F}$. Biff i, Libreria Editrice Vaticana 1985, s. 103.

${ }_{15}$ Pinto de Oliv e ir a, Originalité theologique de Jean Paul II, [w:] Jean Paul II et les droits de l'homme, Fribourg (Suisse) 1980, s. 61-82. 
mentem, który musiał wywrzeć wrażenie i pobudzić do głębokiej refleksji nad wagą problematyki praw człowieka w dzisiejszym świecie, było znalezienie przez Organizację Narodów Zjednoczonych jakiejś płaszczyzny, która umożliwiła sformułowanie tych praw i przyjęcie ich równocześnie przez państwa o tak różnych czy nawet przeciwstawnych sobie ustrojach społecznych i politycznych, opartych na odmiennych zasadach filozoficznych.

Wydaje się, że ogromny dramat drugiej wojny światowej doprowadził niejako do odsłonięcia godności człowieka, do odsłonięcia najgłębszych i nietykaInych racji jego bytu, naturalnych i niezbywalnych jego praw, których negacja może zawsze zagrozić nową tragedią. W ten sposób znaleziono wspólny mianó wnik, wspólną platformę porozumienia, którą jest prawo naturalne i jego normatywny charakter tak w stosunku do sfery sprawiedliwości obiektywnej jak i sprawiedliwości subiektywnej. Było to „odkrycie, że u korzeni doświadczenia praktycznego życia we wspólnocie każdego człowieka jest coś co zjawia się przed jakąkolwiek teorią i co ma, pragmatycznie, wartość bardziej uniwersalną niż teoria"16. Na tej wspólnej platformie, nie wnikając bliżej w zbudowane obok niej różne teorie, łatwo odnalazł się także Kościół, zmuszony niejako trwającą ciągle w świecie sytuacją, w której człowiekowi odmawia się jednego, najbardziej podstawowego prawa, jakim jest prawo do wolności religijnej.

9. Skierowanie uwagi Urzędu Nauczycielskiego Kościoła na problematykę spraw człowieka miało także poważny motyw pastoralny. Pap. Jan XXIII był przekonany, że Kościół, by utrzymać stały kontakt ze światem współczesnym, by — innymi słowy - wzbudzić u człowieka współczesnego zainteresowanie Kościołem, musi nakreślić w swym nauczaniu wizję świata żyjącego w pokoju, świata nie skłóconego, godnego człowieka i musi zaangażować się, właściwymi sobie środkami w to, by nakreślona wizja stała się rzeczywistością ${ }^{17}$. Zaangażowanie się Kościoła w budowanie pokoju na świecie (nie w walkę o pokój, bo to jest pojęcie zupełnie mu obce) jest równoznaczne $\mathrm{z}$ troską o poszanowanie praw osoby ludzkiej. W tym duchu wypowiedział się bardzo wyraźnie Sobór Watykański II ogarniając swoją afirmacją wszystkie prawa człowieka zawarte w „Deklaracji praw człowieka” Organizacji Narodów Zjednoczonych z 1948 r. W tym kierunku poszli w swym nauczaniu pap. Paweł VI i pap. Jan Paweł II. „By człowiek miał zagwarantowane prawo do życia - mówi pap. Paweł VI do wolności, do równości, do kultury, do korzystania z dóbr cywilizacji, do godności osobistej i społecznej, potrzebny jest pokój; gdzie zaś pokój jest zachwiany i traci swą skuteczność, tam też prawa człowieka stają się niepewne i zagrożone; gdzie nie ma pokoju, prawo traci swoje ludzkie oblicze. Tam gdzie

${ }^{16} \mathrm{~A}$. S col a, L'alba della dignità umana. La fondazione dei diritti umani nella dottrina di Jacques Maritain, Milano 1982, s. 166-170.

${ }^{17} \mathrm{P}$. P a v a n, Il momento storico di Giovanni XXIII e della „Pacem in terris”: sua incidenza negli atti conciliari e nella vita della Chiesa e sua influenza nella società contemporanea, [w:] I diritti fondamentali..., s. 153. 
nie szanuje się, nie broni i nie popiera praw człowieka, tam ma miejsce gwałt i oszustwo w stosunku do jego niezbywalnej wolności; tam gdzie ignoruje się albo degraduje jego osobowość, gdzie praktykuje się dyskryminację, niewolnictwo, nietolerancję, tam nie może być prawdziwego pokoju. Jest tak dlatego, że pokój i prawo są w stosunku do siebie wzajemnie jak przyczyna i skutek; pokój sprzyja prawu, a prawo ze swej strony sprzyja pokojowi” ${ }^{18}$. „Uznanie praw człowieka oznacza ścieżkę wiodącą do pokoju, tak jak ze swej strony pokój sprzyja takiemu uznaniu. Człowiek i pokój — mówi pap. Paweł VI — są pojęciami korelatywnymi; są rzeczywistościami które wzajemnie się potrzebują i uzupełniają"19.

Śledząc wydarzenia i dokumenty Kościoła ostatnich lat można odnieść wrażenie, że coraz bardziej koncentruje on swoją uwagę na prawach człowieka. I jest to wrażenie odpowiadające rzeczywistości. Usiłowania zmierzające do zredukowania istoty ludzkiej do sfery czysto materialnej, upatrywanie ideału życia w postawie konsumpcyjnej, ślepe narzucanie czlowiekowi tzw. naukowego ateizmu - a wszystko to stanowi tragiczne znaki naszych czasów — może być traktowane przez Kościół tylko jako odcinanie człowieka od rzeczywistych źródeł jego wielkości i godności, jako zaprzeczenie ostatecznego sensu ludzkiego życia. Dlatego też obrona ludzkich praw, a w tym na pierwszym miejscu korzenia wszystkich tych praw, jakim jest prawo do wolności religijnej, jest dla Kościoła drogą do ocalenia w człowieku pełnego wymiaru jego człowieczeńst$w^{20}$. W tym kontekście nie mogą dziwić słowa pap. Pawła VI: „Godność człowieka ma swoje korzenie w obrazie i odbiciu Boga, istniejących w każdym człowieku. Dlatego też wszyscy ludzie jako osoby są istotnie między sobą równi. Integralny rozwój osobowy jest manifestacją tego obrazu Bożego w nas. W momencie, w którym żyjemy, Kościól osiągnął żywszą świadomość tej prawdy. Wierzy on także bardzo mocno, że promocja praw człowieka jest wymaganiem Ewangelii i że powinna zająć centralne miejsce w jego posługiwaniu"21.

Sądzę, że nie trudno zauważyć jak stara się te wskazania wcielać w życie pap. Jan Paweł II, którego pierwszą encyklikę pontyfikatu określa się jako „magna charta" ludzkich praw i którego nauczanie i podróże apostolskie są tak mocno zespolone $\mathrm{z}$ upominamien się wszędzie i wobec wszystkich o świat bardziej ludzki 22. Encyklika Redemptor hominis zawiera zaskakujące stwierdzenie, że „Człowiek jest i wciąż staje się drogą codziennego życia Kościoła” (RH 21), w nim Kościół dostrzega wielką godność ,jaką człowiek ma w Chrystusie

${ }^{18}$ AAS 60: 1968 s. 772.

19 AAS 61: 1969 s. 83.

${ }^{20}$ F. B iffi, jw., s. $241-242$.

${ }^{21}$ Apel Ojca Sw. Jana Pawła II pt. Diritti dell'uomo e riconciliazione, odczytany podczas Synodu Biskupów w 1974 r.; zob. „L'Osservatore Romano” z dnia 26 października 1974 (s. 5).

${ }^{22}$ Z. Zd ybicka, jw., s. 126-127; F. Biffi, jw., s. 226-242. 
od Ducha Swiętego" (RH 18). Kościół nie jest bezimiennym kolektywem, ale jest wspólnotą osób dążącą do świadomego, dobrowolnego zjednoczenia (communio) z Chrystusem i wzajemnie między sobą poprzez osobowe akty miłości i służenia w prawdzie. Ten osobowy profil Kościoła przejawia się również $\mathrm{w}$ jego istotnej funkcji, jaką jest uświadomienie i obrona w człowieku tego co istotnie ludzkie, osobowe, w uświadomieniu i obronie wartości związanych z jego życiem w prawdzie, miłości i wolności ${ }^{23}$.

10. Obrona ludzkiej godności nie jest więc tylko zobowiązaniem, które Kościół nakłada na społeczność świecką, ale jest ona również posłannictwem Kościoła. Jeżeli tak, to powstaje pytanie, w jaki sposób Kościół w swoim ustawodawstwie gwarantuje prawa osoby ludzkiej i jakie posiada mechanizmy w swoim porządku prawnym pozwalające na ich obronę. Pierwszym etapem takiej gwarancji jest wprowadzenie praw człowieka, niejako wpisanie ich do wewnętrznego ustawodawstwa, zwykle do ustawy konstytucyjnej. Proces ten w odniesieniu do społeczności państwowych jest zaawansowany, chociaż nie jest jeszcze zakończony. Ale Kościół nie posiada ustawy konstytucyjnej w dzisiejszym techniczno-prawnym znaczeniu tego słowa. Swoją strukturę i działanie opiera Kościół na Ewangelii, która niewątpliwie stanowi, w jakimś sensie, jego konstytucję.

Istniały, jak wiemy, próby ułożenia Lex Fundamentalis Ecclesiae, która miała być, oczywiście w sposób analogiczny, rodzajem konstytucji Kościoła, porównywalnym do państwowych ustaw konstytucyjnych, w końcu jednak nie zdecydowano się na jej opublikowanie. W tym właśnie dokumencie, a także w schematach nowego kodeksu prawa kanonicznego usiłowano sformułować katalog praw człowieka dostosowany do tej wspólnoty nadprzyrodzonej, jaką jest Kościół. Nie mogło w tym wypadku chodzić o te same prawa, które są właściwe człowiekowi jako członkowi społeczności świeckiej, sakramentalna natura Kościoła odróżnia go bowiem w sposób zasadniczy od społeczności jaką stanowi państwo. Nie ulega jednak wątpliwości, że żadne z praw chrześcijanina, jako wiernego wszczepionego przez sakrament chrztu św. do Ludu Bożego, nie może być sprzeczne z prawami człowieka przysługującymi mu jako członkowi państwa, będącego społecznością naturalną. Z równą świadomością zdawano sobie sprawę $\mathrm{z}$ tego, że specyficzne prawa wiernych w Kościele mają podwójny fundament: w ludzkiej naturze i w sakramencie odrodzenia, jakim jest chrzest św., a zatem mają też inny wymiar, zgodny z naturą Kościoła, a więc wymiar sakramentalny. Ta dwuwymiarowość praw chrześcijanina nie przekreśla w niczym tej prawdy, że podmiotem praw człowieka i chrześcijanina jest ten sam człowiek w swej godności naturalnej i nadprzyrodzonej24.

${ }^{23}$ Z. Zdybicka, jw., s. 124.

${ }^{24} \mathrm{P}$. B o n n e t, Dechristifidelibus, de eorum iuribus, de laicis, de consociationibus. Adnotationes in Codicem, Romae 1983, s. 30-31; J. K r u k ow s k i, Prawna ochrona uprawnień osoby ludzkiej w Kościele, [w:] Kościót i prawo. Osoba ludzka a struktury kościelne, t. 2, Lublin 1982, s. 225. 
Ostatecznie, różnymi drogami prawa człowieka przedostały się do tekstu promulgowanego przez pap. Jana Pawła II w 1983 r. nowego Kodeksu prawa kanonicznego. Znajdziemy je w różnych księgach nowego Kodeksu. Obowiązki i prawa wiernych, wspólne wszystkim ochrzczonym oraz obowiązki i prawa świeckich znalazły się $\mathrm{w}$ Kodeksie przedstawione w miarę systematycznie, w kan. 208-231. Tymczasem obowiązki i prawa duchownych, wiążące się z pełnionymi przez nich funkcjami kościelnymi nie zostały przedstawione systematycznie, lecz zostały ukazane wraz z opisem pełnionych przez duchownych różnych funkcji.

Kodeks prawa kanonicznego z 1983 r. zawiera zatem, w miarę dzisiejszej świadomości Kościoła, pełny zapis obowiązków i praw członków Kościoła, ale nie jest to katalog obowiązków i praw, który mógłby się pokrywać z katalogiem obowiązków i praw zawartych w uchwale Organizacji Narodów Zjednoczonych z $1948 \mathrm{r}$.

11. Korzystanie z przysługujących chrześcijaninowi w Kościele praw podlega pewnym regułom wynikającym zarówno z godności człowieka jako osoby, jak też z faktu, że żyje on we wspólnocie, która realizuje się poprzez różnorakie więzy łączące go z innymi ludźmi, mniejszymi i większymi wspólnotami wewnątrz i poza Kościołem, ostatecznie zaś łączącymi go z Chrystusem - Głową Kościoła. Te więzy wiary, sakramentów i zwierzchnictwa kościelnego decydują o tym, czy chrześcijanin zachowuje pełną wspólnotę, czy też rozluźnia swój do niej stosunek (zob. kan. 205).

Dlatego też ustawodawca kościelny zwraca uwagę, że: „W wykonywaniu swoich praw, czy to indywidualnie, czy zrzeszeni w stowarzyszeniach, wierni powinni mieć na uwadze dobro wspólne Kościoła, uprawnienia innych oraz własne obowiązki wobec drugich” (kan. 223, §1), oraz że: „Ze względu na dobro wspólne przysługuje władzy kościelnej prawo domagania się, by wierni korzystali z umiarem z przysługujących im praw" (kan. 223, §2).

Te klauzule ograniczające nieskrępowane korzystanie z przysługujących wiernym w Kościele praw, w niczym nie naruszają rzeczywistej wolności człowieka. W rzeczy samej, jeżeli chodzi o pierwszą z tych klauzul, nakładającą na wiernych obowiązek samoograniczenia (autokontroli) w stosunku do ich praw subiektywnych, to stoi ona na straży podstawowej zasady etycznej i prawnej: „neminem laedere" i „unicuique suum tribuere" 25 . Dotyczy ona trzech chronionych prawnie sfer: dobra publicznego, praw słusznie nabytych przez osoby trzecie i własnych obowiązków wiernego w stosunku do osób trzecich ${ }^{26}$. Nie ulega wątpliwości, że ta klauzula wypływa wewnętrznie z pojęcia Kościoła jako wspólnoty ${ }^{27}$.

Wynika stąd pośrednio, że władza kościelna jest uprawniona w niektórych

${ }^{25}$ Commento al Codice di Diritto Canonico a cura di P. V. Pin to, Roma 1985, s. 128.

${ }^{26}$ E. Corecco, jw., s. 112.

27 Tamże, s. 112-113. 
wypadkach do interwencji, jeżeli korzystanie z przysługujących wiernemu praw przekracza nakreślone granice. Mówi o tym druga klauzula, której nie można jednak rozumieć w ten sposób, że władza kościelna może interweniować, kiedy tylko zechce ${ }^{28}$. Po pierwsze, nie może w tych wypadkach chodzić o ograniczenie samego prawa, lecz jedynie ograniczenie korzystania z niego ${ }^{29}$; po wtóre, korzystanie z niektórych praw w ogóle nie może podlegać ograniczeniu, np. korzystanie z prawa do wolności religijnej, do dobrego imienia, do wyboru stanu itp. ${ }^{30}$; po trzecie, sposób interwencji władzy musi się opierać na obowiązujących przepisach prawnych ${ }^{31}$.

Charakter wspólnotowy Kościoła powoduje, że inny jest stosunek wiernych do pasterzy niż odniesienie obywateli do władzy państwowej ${ }^{32}$, niemniej — biorąc pod uwagę niedoskonałość natury ludzkiej — także i w Kościele zdarza się naruszenie prawa $\mathrm{i}$ istnieje potrzeba jego obrony.

Biorąc to pod uwagę prawo kościelne stanowi w kan. 221, § 1: „Wiernym przysługuje legalne dochodzenie i obrona przysługujących im w Kościele uprawnień na właściwym forum kościelnym według przepisów prawa; § 2: Wierni, jeżeli zostali wezwani przed sąd przez kompetentną władzę, mają prawo, by byli sądzeni z zachowaniem przepisów prawa, stosowanych ze słusznością; § 3: Wiernym przysługuje prawo, by nie nakładano na nich kar kanonicznych, jak tylko zgodnie z przepisami ustawy".

Te ogólne zasady proklamujące ochronę praw wiernych we wspólnocie Kościoła, stoją u podstaw całego prawa procesowego, wskazującego istniejące w Kościele środki takiej ochrony, a także częściowo u podstaw prawa karnego, ponieważ określają jego zasięg.

Nie mam zamiaru przedstawiać tutaj skomplikowanych mechanizmów procesowych danych w Kościele do dyspozycji wiernych i władzy kościelnej, chcę jedynie wskazać tytułem przykładu na niektóre charakterystyczne cechy procesu, bardziej bezpośrednio związane z chrześcijańską wizją godności człowieka. Niektóre z tych cech sięgają swoimi korzeniami do Ewangelii i były w Kościele regułą postępowania przez wieki, inne natomiast, jak gdyby z pewnym opóźnieniem doszły do świadomości Kościoła i zostały uwzględnione w kościelnym prawie procesowym w związku z promulgacją nowego Kodeksu.

12. Mówiąc najogólniej można bronić swoich praw w Kościele dwiema drogami: sądową i administracyjną. Jeżeli dla drogi sądowej charakterystycznymi metodami tej obrony są: skarga i zarzut, to dla drogi administracyjnej jest do dyspozycji rekurs od dekretu. Droga sądowa jest bardziej sformalizowana

${ }^{28}$ Tamże, s. 113.

${ }^{29}$ Commento al Codice..., s. 128.

30 Código de Derecho Canónico. Edicion anotada, ed. P. Lo m bardzia, I. Arrieta, Pamplona 1983, s. 180.

${ }^{31}$ The Code of Canon Law. A text and commentary, ed. J.A. Coriden, T.J. Green, D.E. Heintschel, New York 1985, s. 158.

${ }^{32}$ E. Corecco, jw., s. 117. 
i dłuższa, rekurs administracyjny nie posiada wprawdzie tych wad, ale nie rozwinął jeszcze w Kościele w pełni swoich skrzydeł.

Wierni mogą, teoretycznie, bronić w Kościele wszystkich przysługujących im praw; czasem tylko przy pomocy procesu, czasem drogą administracyjną. Trzeba jednak szczerze stwierdzić, że Kościół nie lubi procesów, a jeśli je prowadzi, jeśli posiada prawo procesowe, to jest to niewątpliwie konsekwencją ludzkiej kondycji, którą Kościół zna i z którą się liczy. Ale nawet wówczas, kiedy Kościół bierze pod uwagę ludzką słabość, to mimo wszystko szuka sposobów zażegnania sporów, chociażby sprawa została już wprowadzona na drogę sądową. Takie postępowanie jest $\mathrm{z}$ jednej strony dostosowaniem się do rady św. Pawła, $\mathrm{z}$ drugiej zaś jest $\mathrm{w}$ pełni zgodne $\mathrm{z}$ realizacją chrześcijaństwa w praktyce współczesnego życia. Ta preferencja, jaką Kościół daje w swoim prawie procesowym ugodowemu sposobowi załatwiania kontrowersji jest niewątpliwie jedną $\mathrm{z}$ cech charakterystycznych procesu kościelnego.

Ma rację jeden ze współczesnych kanonistów ubolewając nad tym, że w nowym Kodeksie zasada ta znalazła się nie na samym wstępie księgi VII De processibus, lecz dopiero na początku tytułu III tej księgi w rozdziale I pt. De officio iudicum et tribunalis ministrorum ${ }^{33}$. Ustawodawca tak wyraża tę zasadę w kan. 1446 § 1: „Wszyscy wierni, przede wszystkim zaś biskupi, winni pilnie pracować, by zachowując sprawiedliwość, na ile to możliwe, wykluczyć spory w Ludzie Bożym i jak najszybciej pokojowo je rozwiązywać".

Uderza w tym pouczeniu ustawodawcy odwołanie się do biblijnego obrazu Kościoła jakim jest Lud Boży, i przez to wskazanie na wspólnotowy charakter, a jednocześnie jedność jaką stanowi Kościól. Żaden proces, żadne nieporozumienie między wiernymi nie ogranicza się w nim tylko do jednostek, ale ma zawsze konsekwencje w stosunku do całej wspólnoty Ludu Bożego, którą rani i narusza w mniejszym lub większym stopniu. Czegokolwiek dotyczyłby ten spór, będzie zawsze niepożądany, będzie niszczył dobro jednostek i wspólnoty. Wynika stąd konieczność dołożenia wszelkich starań ze strony każdego członka wspólnoty kościelnej a zwłaszcza tych, którzy za tę wspólnotę ponoszą szczególną odpowiedzialność, czyli biskupów, by najpierw zapobiegali powstawaniu sporów, a wówczas kiedy się one pojawią, by starali się je rozładować w duchu chrześcijańskiej miłości.

Pięknie rozwija tę myśl ks. bp Zenon Grocholewski, sekretarz Sygnatury Apostolskiej. Wskazując na najgłębsze racje, jakimi kieruje się ustawodawca, zaleca unikanie sporów i pokojowe ich załatwianie, a równocześnie uzasadnia konieczność istnienia w Kościele systemu, dzięki któremu w ostateczności można będzie przywrócić naruszony porządek prawny. Autor, rozważając naturę Kościoła, ukazaną w takich pojęciach i obrazach, jak: wspólnota wiernych,

${ }^{33} \mathrm{R}$. B e r tol in o, La tutela dei diritti nella Chiesa dal vecchio al nuovo Codice di Diritto Canonico, Torino 1983, s. 121. 
Lud Boży, Mistyczne Ciało Chrystusa, stara się wyciągnąć wnioski, jakie wynikają z niej dla specyficznego w Kościele sposobu załatwiania sporów, różniącego się zwłaszcza od metod stosowanych w społecznościach świeckich ${ }^{34}$.

13. W tym szerokim kontekście jest rzeczą zrozumiałą, że najwyższym prawem Kościoła jest zbawienie dusz. Świadomość rangi tego prawa towarzyszyła Kościołowi przez całą jego historię, ale dopiero w Kodeksie z 1983 r. zostało ono expressis verbis skodyfikowane ${ }^{35}$. Szkoda, że nie znajdujemy go na samym początku Kodeksu, a właśnie na samym końcu, bo w ostatnim kanonie 1752 i jak gdyby na marginesie drugorzędnej w końcu sprawy, jaką jest sposób postępowania przy przenoszeniu proboszczów. W kanonie tym czytamy: „W sprawach przeniesienia należy stosować przepisy kan. 1747, z zachowaniem kanonicznej słuszności i mając przed oczyma zbawienie dusz, które zawsze winno być w Kościele najwyższym prawem". Można powiedzieć, że w pewnym sensie przez przypadek, najwyższą zasadę prawa kościelnego postawiono na straży wszystkich przepisów Kodeksu, umieszczając ją jako ostani z jego kanonów.

Najwyższy walor zasady zbawienia dusz w kościelnym prawie procesowym pozwala na stwierdzenie, wypowiadane wielokrotnie przez Urząd Nauczycielski Kościoła, a ostatnio często przez pap. Jana Pawła II, że działalność sądowa w Kościele ,jest sama w sobie i ze swej natury pastoralna” 36 , że „,jest integralną i kwalifikowaną częścią urzędu pasterskiego Kościoła" 37 , że sędziowie są „cennymi współpracownikami działalności pastoralnej”"38, że „urząd sędziego kościelnego stanowi posługę prawdziwie kapłańską"39.

14. Z wszystkich tych twierdzeń, które wskazują na specyficzny charakter kościelnego prawa procesowego, nie należy wyciągać wniosku, a trzeba powiedzieć, że były takie usiłowania w niedalekiej przeszłości, że Kościołowi nie jest potrzebne prawo procesowe, skoro załatwianie wszelkich sporów powinno być dokonywane w duchu chrześcijańskiej miłości. Nie tutaj miejsce na dowodzenie, że taka władza nie tylko przysługuje Kościołowi, ale że jest mu także potrzebna na co dzień. Niestety, ze względu na ludzką kondycję niektóre spory w Kościele muszą być skierowane na drogę sądową. Temu stwierdzeniu powinna jednak towarzyszyć świadomość, że wyraźna tendencja kościelnego prawa procesowego do unikania sporów i do rozstrzygania ich drogą pokojową, stanowi jeden z najbardziej szlachetnych sposobów ochrony godności ludzkiej

${ }^{34} \mathrm{Z}$. G roch ol ew sk i, Aspetti teologici dell'attività giudiziaria della Chiesa, „Monitor Ecclesiasticus" 4: 1985 s. 492-494.

${ }^{35} \mathrm{~S}$. Vill e g i a n te, Il diritto di difesa delle parti nel processo matrimoniale canonico. Relazione tenuta a Roma l'8 marzo 1984, [w:] Studi di diritto canonico matrimoniale e processuale n. 2, s. 15 .

36 AAS 71: 1979 s. 425

37 AAS 73: 1981 s. 229

38 AAS 71: 1979 s. 422.

${ }^{39}$ AAS 71: 1979 s. 1529. 
i wypływających z niej praw, a zwłaszcza praw o najwyższej wartości duchowej.

Jeżeli sporu nie udało się zażegnać i został on przedstawiony trybunałowi kościelnemu, to w stosunku do takiej sytuacji kan. 1446 § 2 postanawia: „Sędzia, na początku sprawy, a także w każdym innym czasie, dostrzegając jakąkolwiek nadzieję dobrego wyniku, powinien zachęcić strony i pomóc im, by szukały słusznego rozwiązania sporu przez wspólne porozumienie, i wskazać odpowiednie to tego drogi, korzystając także $\mathrm{z}$ pośrednictwa poważnych osób";

$\S 3$ „Jeżeli spór dotyczy prywatnego dobra stron, sędzia powinien się zorientować, czy nie byłoby pożyteczne zastosować ugodę lub sąd polubowny, zgodnie z przepisami ka. 1713 - 1716".

Z przepisów tych wynika, że mimo wniesienia sporu przed sąd kościeiny istnieje jeszcze możliwość przekazania przynajmniej niektórych spraw albo na drogę umowy albo do sądu polubownego. Obydwie te formy uniknięcia formalnego procesu pozwalają stronom na wykazanie dobrej woli w tym celu, by nie doszło do ostateczności i by sędzia kościelny nie musiał wkraczać w spór całym swoim autorytetem i decydować w sprawie wbrew woli przynajmniej jednej ze stron $^{40}$.

Chociaż dążność do unikania lub przynajmniej lagodzenia sporów stanowi w Kościele ogólną regułę postępowania, to jednak nie może ona mieć zastosowania zawsze i we wszystkich procesach, skoro strony zaangażowane w spór nie chcą skorzystać z tego sposobu i żądają przeprowadzenia formalnego procesu. Sędzia może zawsze, w każdym stadium procesu, zachęcać do pokojowego zakończenia sprawy, nigdy jednak nie może stron do tego zmusić.

15. Zastosowanie sposobów uniknięcia procesu jest zróżnicowane i zależne od rodzaju wniesionej sprawy.

Jeśli chodzi o sprawy karne, pozornie najmniej nadające się do ulgowego ich traktowania, to i w odniesieniu do nich: „Ordynariusz dopiero wtedy powinien wszcząc postępowanie sądowe lub administracyjne celem wymierzenia lub deklaracji kary, gdy uznał, że ani braterskim upomnieniem, ani skarceniem ani też innymi środkami pasterskiej troski nie można w sposób wystarczający naprawić zgorszenia, wyrównać naruszonej sprawiedliwości i doprowadzić do poprawy winnego". Tak wyraźnie zaleca kan. 1341, do którego odsyła $\mathrm{z}$ kolei przepis kan. $1718 \S 1 \mathrm{n} .2$.

W sprawach spornych sędzia posiada największe możliwości, by nie dopuścić do formalnego procesu. W sprawach tych chodzi o dobro prywatne wiernych i wybór sposobu rozwiązania sporu jest całkowicie zależny od ich własnej woli. Kodeks w kan. $1446 \S 2$ wyraźnie nakłada na sędziego obowiązek zachęcenia stron i udzielenia im pomocy, by szukały słusznego rozwiązania sporu we

${ }^{40}$ Bardziej szczególowe opracowanie tego zagadnienia daje R. Bertolino (jw., s. 123-124). 
wspólnym porozumieniu. Strony mogą w tym wypadku, celem rozstrzygnięcia sporu, albo posłużyć się zasadami wybranymi przez siebie, albo przepisami wydanymi w tej sprawie przez Konferencję Biskupów (o ile takie zostały uchwalone), albo odwołać się do przepisów prawa świeckiego, obowiązujących w miejscu, w którym dokonuje się ugoda (zob. kan. 1714).

16. Sprawy małżeńskie, których charakter pastoralny nie ulega żadnej wątpliwości i co wskazywałoby na to, że właśnie one powinny być kierowane na drogę ugodową, wymykają się jednak spod ogólnej zasady. Nie wszystkie $\mathrm{z}$ nich mogą być załatwione ugodowo, nawet gdyby strony zainteresowane wyraziły na to zgodę, lub wprost domagały się takiego ich załatwienia. We wszystkich sprawach małżeńskich, a szerzej mówiąc, we wszystkich sprawach de statu personarum, należy brać pod uwagę dobro publiczne, którym strony procesowe nie mogą dysponować wedle własnej woli, ale jest w nie zaangażowana publiczna władza kościelna, strzegąca zachowania właściwej proporcji między dobrem dusz, czyli dobrem publicznym, a dobrem indywidualnym, prywatnym, osób prowadzących sprawę małżeńską.

Mimo wszystko w sprawach małżeńskich należy dokonać pewnego rozróżnienia. W sprawach separacji małżeńskiej, mimo że dotyczy ona zawsze dobra publicznego (zob. kan. 1696) „sędzia, zanim przyjmie sprawę i ilekroć dostrzega nadzieję dobrego wyniku, powinien zastosować środki pastoralne, by małżonkowie pogodzili się i zostali skłonieni do wznowienia małżeńskiego życia wspólnego". Ten kierunek postępowania tłumaczy się istniejącą często szansą przywrócenia wspólnoty życia małżeńskiego uświęconej sakramentem. Najczęstszą przyczyną separacji bywa niewłaściwe postępowanie jednego z małżonków. Współmałżonek nie zawsze jest w stanie znaleźć inne wyjście z takiej sytuacji i zwraca się o separację. Przy pomocy osób trzecich, zwłaszcza posiadającego autorytet religijny sędziego kościelnego łatwiej zażegna konflikt, łatwiej przebaczy i podejmie próbę życia wspólnego. Powodzenie mediacji sędziego w tych wypadkach nie jest uzależnione od środków prawnych będących do jego dyspozycji, ale raczej od zalecanych przez Kodeks ,środków pastoralnych". Nie sądzę, by w odniesieniu do takich sytuacji ustawodawca musiał wskazywać w szczegółach, o jakie środki duszpasterskie chodzi, jak tego się domagają niektórzy ${ }^{41}$, bo środków takich jest bardzo wiele, a zastosowanie właściwego środka jest uzależnione od okoliczności, takich np. jak religijna dojrzałość zainteresowanych stron, wielkość zaistniałego między nimi konfliktu, jego długotrwałość, nadzieja poprawy itp.

Również w odniesieniu do osób, które przedstawiają trybunałowi kościelnemu skargę o orzeczenie nieważności małżeństwa ustawodawca proponuje pogodzenie się. Wydaje się jednak, że tylko znikomy procent tego rodzaju spraw może uniknąć procesu formalnego. Jeżeli małżonkowie żyją w faktycz-

${ }^{41}$ Zob. R. Bertolino, jw., s. 125. 
nej lub prawnej separacji, zwłaszcza od dłuższego czasu, związali się z innym partnerem, otrzymali rozwód cywilny, zawarli małżeństwo cywilne i mają w nim potomstwo, to praktycznie nie istnieje żadna szansa, by doszli do zgody i doprowadzili do sanowania nieważnie zawartego związku. Raczej w takich okolicznościach z całą energią dążą do uzyskania orzeczenia nieważności małżeństwa, a nawet są zdecydowani kontynuować obrany tryb życia bez uzyskania pozytywnego wyroku. Przyznam się, że w mojej ponad 25-letniej praktyce sądowej nie spotkałem się $\mathrm{z}$ ani jednym wypadkiem sanowania małżeństwa na skutek interwencji sędziego w takich okolicznościach!

Może właśnie dlatego, że te szanse są tak minimalne, Kodeks z 1983 r. ogranicza się do zachęty dość ogólnikowej, zawartej w kan. 1676: „Sędzia, zanim przyjmie sprawę i ilekroć dostrzeże nadzieję dobrego wyniku, powinien zastosować środki pastoralne, by małżonkowie, jeżeli to możliwe, zostali doprowadzeni do uważnienia małżeństwa i do wznowienia wspólnego życia małżeńskiego". Kodeks z 1917 r. dawał pod tym względem bardziej szczegółowe zalecenia w kan. 1965. Zobowiązywał on sędziego, by w wypadku zaskarżenia nieważności małżeństwa $\mathrm{z}$ tytułu braku zgody, odpowiednimi napomnieniami skłonił stronę, która zgody nie wyrazila, do dania takiej zgody. Jeżeli małżeństwo zostało zaskarżone z tytułu nie zachowania wymaganej formy prawnej lub z tytułu istniejącej przeszkody zrywającej, sędzia powinien był nakłonić strony do ponownienia zgody małżeńskiej w wymagany prawem sposób, względnie do uzyskania dyspensy od przeszkody zrywającej ${ }^{42}$.

17. Zachętę, a nawet swego rodzaju zobowiązanie do zastosowania drogi pojednawczej spotykamy też w przepisach określających sposób załatwiania sporów administracyjnych. Dość często słyszy się ubolewanie, że w nowym Kodeksie Kościół nie zdołał stworzyć przejrzystego systemu postępowania administracyjnego, że nie zadecydował o powołaniu do życia trybunałów administracyjnych, po których wiele się spodziewano ${ }^{43}$. Trudno określić co rzeczywiście stanęło na przeszkodzie stworzeniu trybunałów, mimo gotowego już projektu, ale wiadomo też, że niektóre konferencje biskupów wyraźnie się im sprzeciwiły ${ }^{44}$. Z przychylną oceną biskupów spotkały się natomiast propozycje, których celem było określenie w kościelnej procedurze administracyjnej środków odwoławczych zapobiegających powstaniu sporów administracyjnych. Komisja Kodyfikacyjna zaproponowała takie środki w schemacie De procedura administrativa z 1972 r. Przyjęto je z życzliwością ponieważ miały one bardziej pastoralny niż prawny charakter i przez to bliższe były chrześcijańskiej idei pojednania i braterskiej miłości, które powinny cechować stosun-

${ }^{42} \mathrm{P}$. W e s e m a n n, Il tribunale di I istanza ed i suoi compiti pastorali, „Monitor Ecclesiasticus" 3: 1984 s. 345.

43 J. G a r cia Failde, Una primera lectura del nuevo Codigo de derecho procesal canonico, „Revista Espanola de Derecho Canonico" 39: 1983 s. 149.

44 J. Kruk owski, Administracja w Kościele. Zarys kościelnego prawa administracyjnego, Lublin 1985, s. 203. 
ki nie tylko między wiernymi, ale także między podwładnymi i przełożonymi w Kościele. Wprawdzie uznanie przez Kodeks z 1983 r. środków zapobiegających powstaniu sporu w postępowaniu administracyjnym stanowi nowość w stosunku do Kodeksu z 1917 r., ale jest to krok zgodny z dawniejszą praktyką Kościoła, znaną już w Dekrecie Gracjana i w prawdzie Dekretałów. Aktualny Kodeks dopuszcza kilka takich środków zaradczych, a mianowicie:

$1^{\mathrm{o}}$ - prośba do autora aktu administracyjnego (dekretu) o odwołaniu go lub poprawienie;

$2^{\mathrm{o}}$ - zwrócenie się osoby pokrzywdzonej dekretem i równocześnie autora aktu administracyjnego o rozsądzenie sprawy do mediatorów;

$3^{o}$ - przekazanie spornej sprawy do rozpatrzenia przez stały urząd lub radę, ustanowione w tym celu przez Konferencję Biskupów i zgodnie z normami przez nią ustalonymi, a jeśli ich brak, to przez urząd lub radę powołaną przez samego biskupa ${ }^{45}$.

Trudno tutaj zajmować się szczególami tego zagadnienia, wymagałoby to osobnego studium. Ważne jest by zauważyć, że istnienie mechanizmów, służących do wyciszenia powstającego nieporozumienia między wiernymi a władzą kościelną dowodzi, jak bardzo ustawodawcy leży na sercu pojednanie zwaśnionych stron w duchu chrześcijańskim, by nie doszło do wniesienia rekursu administracyjnego, który uruchamia formalne postępowanie administracyjne.

18. Istnienie trybunałów kościelnych i rozgałęzionego systemu prawa procesowego we wspólnocie kościelnej wskazuje na to, że natchnione Ewangelią zachęty i przepisy mające zapobiec procesom po prostu nie wystarczają.

Sytuacja Kościoła w dziedzinie procesowej nie jest żadną tajemnicą i przedstawia się mniej więcej w ten sposób, że sprawy karne trafiają przed trybunały kościelne bardzo rzadko i są to niemal z reguły sprawy, w których za swoje przestępstwa odpowiadają duchowni. Nie wynika $\mathrm{z}$ tego, niestety, by inni członkowie wspólnoty kościelnej nie popełniali czynów zasługujących na karę. Nie od dziś Kościół zrezygnowal ze ścigania przestępstw pospolitych i od wieków zajmuje się tym władza świecka, zarówno na zasadzie własnej kompetencji, jak i w oparciu o dwustronne, zwykle konkordatowe umowy z Kościo$\nmid \mathrm{lem}^{46}$, czasem zaś po prostu przez uzurpację. Podobna sytuacja istnieje w sprawach spornych, przede wszystkim w odniesieniu do świeckich: mogą oni i wolą przedstawiać swoje spory trybunałom cywilnym, co gwarantuje im większą skuteczność wyroków tam uzyskanych. $\mathrm{Z}$ tego rodzaju spraw trafiają do trybunałów kościelnych niższego i wyższego stopnia jedynie spory między instytucjami kościelnymi, czasami również między jednostkami duchownymi lub świeckimi a instytucjami kościelnymi (tzw. causae iurium). Sądownictwu kościelnemu pozostają do załatwienia sprawy małżeńskie, wśród których, w zależ-

45 Tamże, s. $204-209$.

46 Zob np. art. 22 konkordatu Polski ze Stolicą Apostolską z r. 1925 (AAS 17: 1925 s. 281). 
ności od sytuacji danego kraju określonej obowiązującym tam ustawodawstwem cywilnym, dominują albo sprawy o separację, albo o orzeczenie nieważności małżeństwa. Nie wszyscy może wiedzą, że np. w Polsce od 1946 r. w ogóle sądy kościelne nie prowadzą spraw o separację, a tylko procesy o orzeczenie nieważności małżeństwa. Wynika to $\mathrm{z}$ faktu przejęcia przez władze państwowe całości polityki rodzinnej, co spowodowało, że gdyby nawet Kościół orzekał separację, to i tak jego wyroki nie pociągałyby za sobą żadnych skutków cywilnych.

Są również, a zwłaszcza były w niedalekiej przeszłości kraje, gdzie prawie nie prowadzono spraw o orzeczenie nieważności małżeństwa, natomiast rozstrzygano bardzo dużo spraw o separację.

Analizując działalność sądownictwa kościelnego w sprawach małżeńskich, w tych krajach, w których wyrok trybunału kościelnego nie powoduje żadnych skutków cywilnych, łatwo dostrzec jakim celom służy ta działalność. Okazuje się, że zmierza ona do czysto pastoralnych celów, do ustalenia faktu zaistnienia lub niezaistnienia sakramentalnego małżeństwa, dzięki czemu strony procesowe mogą rozwikłać swoje wewnętrzne trudności i odzyskać spokój sumienia. Ilustruje to w sposób ewidentny zarówno odmienność celów procesu kanonicznego w stosunku do procesu cywilnego jak i konieczność innego sposobu posługiwania się prawem kanonicznym, chroniącym wyższe, duchowe wartości.

19. Jakikolwiek byłby zakres realnego zasięgu sądownictwa kościelnego, to jednak teoretycznie i nierównomiernie w praktyce, funkcjonuje w Kościele cały aparat sądowniczy: karny, sporny, w sprawach małżeńskich i od pewnego czasu również system postępowania administracyjnego. Funkcjonowanie tego systemu wskazuje na to, że ochrona godności ludzkiej w Kościele nie została ograniczona do sfery idealnych stosunków międzyludzkich, ale bierze również pod uwagę zachowania, które przekroczyły już pewien próg i kwalifikują się jako prawdziwy dramat osobisty lub społeczny, wymagający interwencji Kościoła jako sędziego.

Jaką odpowiedź może dać Kościół na ten dramat?

Otóż specyfiką prawa kościelnego w ogóle, w tym również kościelnego prawa procesowego jest obrona rzeczywistych wartości, która ostatecznie sprowadza się do obrony nadprzyrodzonego, ostatecznego dobra człowieka. Każdy proces, w jakiś sposób, przynajmniej czasowo, narusza właściwą hierarchię wartości, chociaż w końcu zmierza do jej przywrócenia. Dlatego też, odwołując się do prawa procesowego jako do systemu, który stoi na straży godności człowieka, musimy sobie zdawać sprawę z tego, że największy walor w obronie tej godności i praw mają zasady podstawowe, zaś szczegółowe przepisy, poszczególne instytucje prawa procesowego nie są niczym innym jak tylko instrumentem, ważnym wprawdzie, a czasem niezbędnym, ale tylko instrumentem 
w obronie tych praw ${ }^{47}$.

20. Wśród zasad podstawowych, oprócz wymienionej już cechy pastoralności prawa kościelnego i w konsekwencji także procesu kanonicznego, oprócz charakterystycznej dla tego procesu tendencji do unikania sporów, należałoby zwrócić uwagę na ograniczone stosowanie w Kościele zasady legalności oraz na potrzebę stosowania prawa w duchu słuszności kanonicznej.

Przykładem uszanowania jakie prawo procesowe zachowuje dla każdej osoby ludzkiej jest to, że dopuszcza ono tylko bardzo wyjątkowo dowody legaIne, nie zna formalizmu prawnego, a sędzia kościelny jest zawsze wolny w ocenie dowodów zgodnie z kryteriami moralnymi ${ }^{48}$. Sprawiedliwy wyrok, do którego wierni mają ścisłe prawo, ma być wydany zgodnie z przepisami prawa, ale stosowanymi ze słusznością kanoniczną. Zasada słuszności kanonicznej od wieków uchodzi w Kościele za gwarancję poszanowania godności ludzkiej49, chociaż nie zawsze w historii rozumiano ją jednakowo. Wydaje się, że nie można tej zasady zredukować ani do słuszności naturalnej (w takim znaczeniu została ona wypracowana w prawie rzymskim), ani też nie można jej ograniczyć do słuszności zawartej w prawie pisanym (tzw. aequitas constituta), ale należy ją rozszerzyć na słuszność nie pisaną (tzw. aequitas non scripta), dzięki czemu może się ona stać rzeczywiście czynnikiem kontrolującym istniejące normy, korygującym je w konkretnych przypadkach, a także czynnikiem umożliwiającym tworzenie sprawiedliwych norm prawa pozytywnego ${ }^{50}$.

21. Po tym bardzo pobieżnym wskazaniu zasad procesu kanonicznego strzegących godności i praw człowieka, chciałbym przejść do niestety również pobieżnego omówienia niektórych gwarancji praw osoby ludzkiej istniejących w aktualnie obowiązującym kościelnym ustawodawstwie procesowym, zwracając szczególną uwagę na te jego elementy, które stanowią pewną nowość w stosunku do Kodeksu z 1917 r. Tym sposobem łatwiej zauważyć, jakiego postępu dokonano $\mathrm{w}$ prawie procesowym na przestrzeni ostatnich lat $\mathrm{w}$ dziedzinie ochrony praw ludzkich.

Przezwyciężając uprzedzenia, które ciążyły na dawnym prawie, nowy Kodeks poszerza krąg osób, które mogą w Kościele bronić swych praw. Już dnia 8 stycznia 1973 r. Papieska Komisja Interpretacji Dekretów Soboru Watykańskiego II zezwoliła niekatolikom, ochrzczonym i nieochrzczonym, na prowadzenie w sądach kościelnych praw małżeńskich ${ }^{51}$, ale dopiero w Kodeksie z 1983 r. ta możliwość została rozciągnięta na wszystkie rodzaje spraw. Wydaje się również, że wobec zniesienia kan. 1654 starego Kodeksu, mogą obecnie

${ }^{47} \mathrm{~S}$. Villeggiante, jw., s. 13 (nota n. 16).

${ }^{48}$ R. Bertolino, jw., s. 115.

${ }^{49} \mathrm{M}$. Ż u r ow s k i, Stuszność prawna ochronq godności człowieka, „Przegląd Powszechny” $7 /$ 8: 1986 s. 91-105.

${ }^{50} \mathrm{~F}$. U r r u ti a, Aequitas canonica, „Periodica de re morali, canonica, liturgica” 1: 1984 s. 69.

51 „Communicationes” 1: 1973 s. 39. 
stare in iudicio także osoby ekskomunikowane ${ }^{52}$.

Jeszcze większe znaczenie praktyczne ma dopuszczenie do zaskarżenia nieważności małżeństwa tych małżonków, którzy byli bezpośrednią i umyślną przyczyną (causa directa et dolosa) nieważności zawartego przez siebie związku (zob. kan. $1674 \mathrm{n} .1$ ). W dawnym prawie nie mogli oni zaskarżać bezpośrednio swego małżeństwa, było to bowiem zarezerwowane rzecznikowi sprawiedliwości. Odmowa tego prawa miała wyraźnie charakter represyjny, a komentatorzy tego zakazu zawsze powoływali się na zasadę, że: nemo auditur propriam turpitudinem allegans (C. 1, X, IV , 7) ${ }^{53}$. Nie negując, sądzę, prawdziwości tej motywacji, ustawodawca zniósł obecnie wszelkie ograniczenia w tym względzie, powołując się na racje pastoralne ${ }^{54}$.

Została także poszerzona możliwość zmiany procesu małżeńskiego na postępowanie administracyjne celem uzyskania dyspensy od małżeństwa nie dopełnionego. W dawnym Kodeksie takie przejście było ograniczone tylko do spraw, w których nieważność małżeństwa została zaskarżona z tytułu impotencji (zob. Instr. „provida”, art. 206), obecnie zaś jest ono możliwe we wszystkich sprawach małżeńskich, z jakiegokolwiek toczyłyby się one tytułu (kan. 1681). Jest to duże ułatwienie praktyczne odstępujące od poprzedniej nadmiernie sformalizowanej procedury i pozwalające na załatwienie tego typu spraw małżeńskich w krótszym czasie.

Zostały zniesione w pewnym sensie dyskryminacyjne zakazy, jakie w poprzednim Kodeksie w kan. 1652 dotykały zakonników. Dzisiaj, na równi z innymi, posiadają oni personam standi in iudicio ${ }^{55}$.

22. Poważnym zagadnieniem dzisiejszej kanonistyki, bezpośrednio związanym $z$ naszym tematem jest prawo do obrony w procesie. Wokół tego zagadnienia rozwinęła się ostatnio ciekawa dyskusja, z której wynika, że należałoby dość zasadniczo zmienić poglądy na istotę prawa obrony, jakie panowały dotychczas w nauce. Podstawami, na których należałoby oprzeć taką zmianę poglądów są z jednej strony teoretyczne studia dotyczące zasady kontradykcyjności, zwłaszcza w sprawach o orzeczenie nieważności małżeństwa, z drugiej zaś strony nowe ustawodawstwo kościelne w tej kwestii.

Jeszcze stosunkowo niedawno temu uważano powszechnie, że prawo do obrony w procesie wyplywa $\mathrm{z}$ prawa natury, naruszenie zaś tego prawa traktowano jako równoznaczne $\mathrm{z}$ naruszeniem prawa naturalnego. Analiza istoty procesu i to procesu w ogóle, pozwoliła na wysunięcie wniosku, że kontradykcyjność, tzn. przeciwstawianie się jednej strony w procesie drugiej stronie, żą-

52 J. Garcia Failde, jw., s. 149.

${ }^{53} \mathrm{~S}$. B is k u p s k i, Prawo matżeńskie Kościota rzymsko-katolickiego. T. 2: Proces matżeński, Olsztyn 1960 , s. $140-141$.

54 "Communicationes” 2 : 1970 s. 189.

55 Z. G r o ch ol e w s k i, Panoramica sulle novità del nuovo diritto processuale canonico, [w:] Il matrimonio nel nuovo Codice di Diritto Canonico. Annotazioni di diritto sostanziale e processuale, Padova 1984, s. 189. 
dania jednej strony i negowanie tych żądań przez drugą stronę, są tak właściwe każdemu procesowi, że nie mógłby on istnieć bez kontradykcyjności. Jest ona elementem niezbędnym każdego procesu, tworzy ten proces. Stąd też prawo do obrony, polegające na możliwość przeciwstawienia się oskarżeniu wypływa $\mathrm{z}$ samej istoty procesu, ex natura rei, nie zaś bezpośrednio ex iure naturali.

$\mathrm{O}$ ile nie ma trudności z dostrzeżeniem kontradykcyjności w procesie karnym czy w postępowaniu administracyjnym, o tyle w procesie o orzeczenie nieważności małżeństwa jest ona, w tradycyjnym rozumieniu, bardzo problematyczna. Problematyczność ta wynika najpierw stąd, że w tych procesach stosunkowo często obydwie strony walczą o to samo, a mianowicie o orzeczenie nieważności małżeństwa, walczą przeciwko małżeństwu, a nie przeciwko sobie. Po wtóre, jeżeli nawet jedna ze stron oskarża nieważność małżeństwa, druga zaś broni jego ważności, to i tak bezpośrednim przedmiotem sporu nie jest stan małżeński stron, o którego zmianę stronom właśnie chodzi, ale umowa małżeńska między stronami, od której istnienia lub braku zależy ważność lub nieważność ich wzajemnego stosunku prawnego.

Wydaje się także, że procesu małżeńskiego nie można uznać za proces toczący się między stronami będącymi w konflikcie. Małżeństwo jest bowiem rzeczywistością sakramentalną; jego istnienie lub nieistnienie rzutuje w zasadniczy sposób na stan osobowy stron, stąd też są one z zasadniczych względów zainteresowane stwierdzeniem prawdy obiektywnej. Do stwierdzenia tej prawdy powołany jest sędzia kościelny, który kierując procesem i wzywając do ujawnienia całej prawdy o małżeństwie zarówno strony procesowe, jak i świadków, staje się prawdziwym dominus causae. Obrona dobra publicznego w procesie małżeńskim identyfikuje się z obroną dobra indywidualnego, prywatnego obydwu stron. Wszyscy, sędzia i strony, zmierzają niejako do jednego celu, do wykrycia tego co można nazwać veritas sacramenti. Nie można w tym wypadku mówić o prawie jednej ze strony do obrony, bo obydwie strony mają jednakowy interes w wykryciu prawdy i mają jednakowy obowiązek współpracy z sędzią kościelnym celem jej stwierdzenia. Sam sędzia staje się w tych procesach obrońcą, zaś istniejąca w innych procesach różnica między prawdą procesową a prawdą obiektywną ulega w nich całkowitemu zatarciu. Proces małżeński nie jest procesem stron także i dlatego, że brak jest w nim prawdziwego zwycięzcy i zwyciężonego. Sędzia, który ma obowiązek orzekania nie według przytoczonych przez strony dowodów, lecz według własnego sumienia, nie stoi jedynie przed alternatywą przyznania racji jednej stronie a odmówienia jej drugiej stronie, ale ma jeszcze w niektórych wypadkach, wyraźnie wskazanych przez prawo, powinność opowiedzenia się za ważnością małżeństwa na zasadzie favor iuris, którym cieszy się zaskarżone małżeństwo ${ }^{56}$.

W tym kontekście można zrozumieć przepis kan. 1481 § 3, według którego

${ }^{56}$ S. Villeggiante, jw., s. 17-21. 
w sprawach małżeńskich nie jest rzeczą konieczną ustanawianie obrońcy, mimo że istnieje taki obowiązek w sprawach karnych (kan. 1481 § 2) i w sprawach spornych dotyczących bądź dobra publicznego bądź osób nieletnich (kan. 1481 § 3). Swoją drogą budzi zastanowienie fakt, że pod tym względem nowy Kodeks jak gdyby uczynił krok w tył, ponieważ w starym Kodeksie wymagano w procesie małżeńskim obecności adwokata (kan. 1655 § 2), chociaż z praktyki wiadomo, że w niektórych krajach, np. w Polsce od czasów II wojny światowej adwokaci byli wielką rzadkością ${ }^{57}$, a nawet można się było spotkać $\mathrm{z}$ głosami sprzeciwu ze strony władzy kościelnej w stosunku do ich udziału w procesach małżeńskich ${ }^{58}$.

Co prawda strona w procesie może się bronić sama, ale jeżeli zdecyduje się na wybór obrońcy, co na ogół jest rzeczą bardzo pożądaną dla jej własnej korzyści, to ma dzisiaj szerszy wybór niż dawniej. Do pełnienia funkcji adwokata zostali dopuszczeni - jeżeli naturalnie spełniają wymagane przez prawo warunki - zakonnicy i zakonnice, na co stary Kodeks nie zezwalal (zob. kan. 1657 § 3).

Dla ułatwienia stronom procesowym obrony, ustawodawca wystąpił w kan. $1490 \mathrm{z}$ bardzo interesującą sugestią, bo przy trybunałach kościelnych powstały zespoły stałych adwokatów, będących na utrzymaniu trybunału. Spośród nich, zwłaszcza w sprawach małżeńskich, strony będą sobie mogły wybrać adwokata lub pełnomocnika ${ }^{59}$. Ta swego rodzaju figura publicznego obrońcy ${ }^{60}$ ma pomóc stronom w znalezieniu osób kwalifikowanych, cieszących się zaufaniem trybunału, ale istnienie takiego zespołu nie zobowiązuje stron do wybrania swego obrońcy tylko spośród tego gremium. Będzie natomiast rzeczą naturalną, że jeżeli trybunałowi przyjdzie wyznaczyć komuś obrońcę, $\mathrm{np} . \mathrm{z}$ racji przyznanego stronie gratuitum patrocinium, to posłuży się on jednym ze swoich adwokatów, chociażby tylko ze względów czysto ekonomicznych ${ }^{61}$.

23. Sa jeszcze do odnotowania inne zmiany w stosunku do roli adwokata w procesie, ułatwiające mu obronę, a więc ważne dla stron procesowych. Pierwszą $\mathrm{z}$ tych zmian jest przyznanie adwokatowi w procesie równych praw z obrońcą węzła i rzecznikiem sprawiedliwości ${ }^{62}$. Dawne prawo było przychylniejsze dla obu tych urzędników trybunału i stawiało ich w pozycji uprzywilejo-

${ }^{57}$ Byli m. i. w Krakowie i w Kielcach.

58 Sprzeciw taki zostal oficjalnie wyrażony przez kard. A. Hlonda.

${ }^{59} \mathrm{M}$. Po m pe d d a, Diritto processuale nel nuovo Codice di Diritto Canonico: revisione o innovazione? Relazione tenuta a Roma il 17 febbraio 1983, [w: ] Studi di diritto canonico matrimoniale a processuale, n. l, Roma [bez daty wydania], s. 19.

60 Z. Grocholews ki, Panoramica..., s. 189.

${ }^{61}$ Código de Derecho Canónico. Edicion bilingüe comentada por los professores de la Faculdad Pontificia de Salamanca. Direccion L. de Ech ever ria, Madrid 1983, s. 731; zob. również: R. Bertolino, jw., s. 106-107.

62 P. Ci p r o t ti, Prospettive della procedura giudiziaria della Chiesa, „Monitor Ecclesiasticus” 1: 1972 s. 118. 
wanej. Wyrażała się ona czy to w łatwiejszym dostępie do dokumentacji procesu w czasie jego trwania, czy też w prawie do ostatniego głosu. Dzisiaj wszyscy trzej mają te same uprawnienia procesowe: mogą być obecni podczas przesłuchania stron, nisi iudex propter rerum et personarum adiuncta censuerit secreto esse procedendum (kan. 1559), podczas przesłuchania świadków i biegłych, stawiając im pytania za pośrednictwem sędziego (kan. 1678 \& 1, n. 1), mogą zapoznać się z aktami sądowymi, mimo że nie nastąpiła jeszcze publikacja w procesie.

W procesie karnym oskarżonemu i jego obrońcy przysługuje ostatnia replika (kan. 1725), a w postępowaniu administracyjnym, w wypadku złożenia rekursu hierarchicznego, odwołujący się może skorzystać z pomocy obrońcy, a kiedy przełożony uzna to za konieczne, może nawet otrzymać obrońcę z urzędu.

Wszystkie te szczegółowe przepisy regulujące funkcję obrońcy w procesie świadczą o wielkiej trosce ustawodawcy o zapewnienie stronom procesowym wystarczającej obrony. Należy jednak zauważyć, że nie są to jedyne przepisy służące w Kodeksie zabezpieczeniu interesów stron. Można bez ryzyka stwierdzić, że podobną, a niejednokrotnie ważniejszą rolę w zabezpieczeniu praw ludzkich odgrywają inne zasady czy normy odnoszące się do poszczególnych procesów, a czasem nawet wydawać by się mogło drugorzędne okoliczności, od których zależy właściwy wymiar sprawiedliwości.

W reformie procesu małżeńskiego np., kierowano się zasadami przejętymi w stosunku do rewizji całego Kodeksu, uchwalonymi przez Synod Biskupów w 1969 r., szczególne jednak znaczenie miały te spośród nich, które zmierzały do przyspieszenia procesów małżeńskich i do zabezpieczenia przez te procesy dobra duchowego wiernych ${ }^{63}$. Cechą charakterystyczną tych procesów, odnoszącą się także do innych spraw de statu personarum jest poszukiwanie prawdy obiektywnej. Jest ona w tych sprawach tak ważna, że wyrok, jaki został orzeczony nie przechodzi nigdy w stan rzeczy osądzonej i może być zawsze zmieniony, ilekroć znajdą się dowody przeciwne. Te jedyne w swoim rodzaju przepisy prawa procesowego stoją od wieków na straży rzeczywistości sakramentalnej, która „dotyka Kościoła w jego najbardziej witalnej strukturze"64 i jego służby człowiekowi w najistotniejszych dla niego sprawach.

24. Poważnym osiągnięciem na rzecz obrony godności człowieka jest przyjęta do kościelnego prawa karnego zasada: nullum crimen, nulla poena sine lege poenali praevia, czyli zasada legalności w sferze karnej, mająca znaczenie także w procesie karnym. Nie była ona wprawdzie zupełnie obca dawnemu prawu karnemu, ale w Kodeksie z 1983 r. uzyskała nowe gwarancje, zwłaszcza przez zakaz analogicznego stosowania ustawy karnej (kan. 19). Trzeba jednak

${ }^{63}$ T. Pieronek, Proces matżeński w nowym Kodeksie Prawa Kanonicznego (zagadnienia wybrane), „Analecta Cracoviensia” 18: 1986 s. 369.

${ }^{64}$ E. Corecco, jw., s. 122. 
przyznać, że zasada nulla poena sine lege, nie może mieć w Kościele pełnego zastosowania, Kościół bowiem mając na względzie dobro dusz, które jest jego naczelną normą i misją, musi się liczyć z wypadkami działania na szkodę człowieka, jakich prawo karne nie przewidzialo i jakim nie można inaczej zaradzić, jak tylko uciekając się do kary. Dlatego też zasadę „nulla poena sine lege” stosuje się w Kościele dość elastycznie, zwłaszcza ze względu na konieczność obrony duchowego dobra człowieka ${ }^{65}$.

Tego rodzaju przykładów lepszego zrozumienia dla przepisów prawa jako środków obrony godności człowieka można przytoczyć wiele. Nie sądzę jednak, by nawet na podstawie analizy całości przepisów procesowych nowego Kodeksu, można sobie wyrobić opinię czy jest to już system dobry. Jak na tych kilka lat, które upłynęły od jego wejścia w życie, zdołano mu już wykazać wiele niekonsekwencji, wskazano też wiele bezspornych jego zalet. Nie ulega wątpliwości, że nowe przepisy procesu kanonicznego stanowią skuteczniejszy instrument obrony godności człowieka niż ten, którym dysponowaliśmy dotąd.

Czas okaże, czy w praktyce życia codziennego Kościoła będzie on tym celom służył w sposób wystarczający.

\section{LA TUTELA DEI DIRITTI DELLA PERSONA UMANA NEL DIRITTO PROCESSUALE CANONICO}

Riassunto

La dignità dell'uomo si rivela nel dramma. Soprattutto quando l'uomo non può più salvare la propria vita, vuole conservare la propria dignità e la svela, la percepisce e la sperimenta. Alla dignità umana è legata indissolubilmente la concezione dell'uomo come persona. La persona umana può scoprire il suo valore soltanto grazie al suo rapportarsi all'altro uomo, che constituisce anch'esso un valore. Da qui deriva l'affermazione che la persona umana è soggetto del diritto. La dignità dell'nuomo si manifesta nel fatto che egli è scopo, e non il mezzo dell'attività umana, e richiede la libertà, affinchè l'uomo realizzi se stesso non soltanto nella vita materiale ma anche quella spirituale.

Una grande minaccia per la digmità umana è la violazione degli obiettivi ed inviolabili diritti dell'uomo e fra questi soprattutto il diritto alla libertà religiosa. Il profilo personale della Chiesa si

65 Zob. L G e ros a, La scomunica è una pena? Saggio per una fondazione teologica del diritto penale canonico, Fribourg 1984, s. 382-385. 
manifesta nella sua funzione essenziale, quale è il rendere consapevole ed il diffendere nell'uomo ciò che è essenzialmente umano, personale, il rendere consapevole l'uomo dei valori legati alla sua vita nella verità, nell'amore e nella libertà e la difesa di essa. La difesa della dignità umana non è soltanto un obbligo di cui la Chiesa impone alla società laica, ma è anche la missione della Chiesa. Se è cosi sorge la domanda sul modo in cui la Chiesa, nella legislazione canonica garantisce i diritti della persona umana e sui mecchanismi che essa possiede nel suo ordine giuridico per difendere tali diritti.

L'autore cerca di dare la risposta a questa domanda analizzando sia le regole generali di diritto canonico, sia quelle specifiche del diritto processuale canonico ed illustra il modo della tutela dei diritti del cristiano al interno dell'ordinamento processuale canonico con dei cambiamenti avvenuti in quell'ordinamento nel nuovo Codice di Diritto Canonico, promulgato dal papa Giovanni Paolo II nel 1983. 